\title{
LEMBAGA PEMASYARAKATAN DALAM MENJALANKAN REHABILITASI TERHADAP NARAPIDANA NARKOTIKA
}

\author{
Ibrahim Nainggolan \\ Fakultas Hukum \\ Universitas Muhammadiyah Sumatera Utara \\ ibrahimnainggolan@umsu.ac.id
}

\begin{abstract}
Abstrak
Sistem peradilan pidana lebih diarahkan pada masalah pemidanaan. Pembalasan (The retributivist approach) memandang pemidanaan sebagai suatu tanggapan moral yang pantas dan/atau diperlukan terhadap tindakan terlarang. Di antara berbagai jenis pemidanaan, pidana penjara (pemasyarakatan) merupakan yang paling populer, dan jumlah penghuninya terus meningkat. Lembaga permasyarakatan diharapkan menjalankan sistem pemasyarakatan agar terpidana narkotika (atau yang dikenal sebagai warga binaan pemasyarakatan/WBP) menyadari kesalahan, memperbaiki diri, tidak mengulangi tindak pidana sehingga, dapat diterima kembali oleh lingkungan masyarakat, dapat aktif berperan dalam pembangunan, dan dapat hidup secara wajar sebagai warga yang baik dan bertanggung jawab, dan tidak menjadi residivis. Penulisan ini menggunakan metode penelitian hukum yuridis normatif (normatif research) dengan spesifikasi penelitian deskriptif analistis yang memggunakan data skunder. Prosedur pengumpulan datanya adalah berupa dokumentasi catatan atau kutipan, penelusuran literatur hukum, buku-buku dan lainnya yang bertalian dengan identifikasi masalah baik secara cara offline maupun online yang kemudian dianalisa melalui metode analisa konten (centent analysis method) dengan fokus pada permasalahan tentang Bagaimana rehabilitasi terhadap pelaku tindak pidana penyalahgunaan narkotika yang diselenggarakan Lembaga Pemasyarakatan?, Bagaimana kebijakan Lembaga Pemasyarakatan dalam pelaksanaan rehabilitasi terhadap pelaku tindak pidana penyalahgunaan narkotika?. Dari hasil penelitian diketahui bahwa Penetapan pelaksanaan rehabilitasi terhadap pengguna narkoba merupakan salah satu bagian dari vonis yang dijatuhkan oleh Hakim dan tempat dimana Vonis itu dilaksanakan seharusnya adalah adalah lembaga Pemasyarakatan, bukan ditempat lain. Hal yang sangat disayangkan adalah kurangnya perhatian pemerintah maupun pihak-pihak pembuat kebijakan lain untuk mengatur hal-hal yang bersifat detail mengenai bagaimana hal itu diterapkan. Akibatnya adalah aturan hukum sebagaimana yang disebutkan dalam Undang-undang Psikotropika maupun Narkotika mengenai penerapan hukuman rehabilitasi tersebut hanyalah tinggal pemanis undang-undang tersebut saja tanpa dapat benar-benar secara nyata dan menyeluruh diterapkan dalam aplikasinya dilapangan. Lembaga Pemasyarakatan, harus diakui sudah banyak mengeluarkan kebijakan-kebijakan yang dapat mengakomodir hak-hak dari para Terpidana kasus Narkoba. Namun hal itu masih dalam taraf yang bersifat umum, sedangkan dalam hal-hal khusus seperti penanganan terhadap Terpidana Narkoba yang berada pada tingkat hanya sebagai pengguna masih belum cukup diperhatikan.
\end{abstract}

Kata kunci: Lembaga Pemasyarakatan, Rehabilitasi, Narapidana Narkotika.

\section{PENDAHULUAN}

Indonesia adalah negara yang berdasarkan atas hukum (rechtsstaat), bukan berdasarkan atas kekuasaan belaka (machtsstaat). Pernyataan tersebut secara tegas tercantum dalam Penjelasan Umum Undang-Undang Dasar 1945. Hal ini menunjukkan bahwa Indonesia adalah negara hukum dan sebagai negara hukum, Indonesia menerima hukum sebagai ideologi untuk menciptakan ketertiban, keamanan, keadilan serta kesejahteraan bagi warga negaranya. Konsekuensi dari itu semua adalah bahwa hukum mengikat setiap tindakan yang dilakukan oleh warga negara Indonesia.

Hukum mengatur hubungan hukum. Hubungan hukum itu terdiri dari ikatan-ikatan antara individu dan masyarakat dan antara individu itu sendiri. Ikatan-ikatan itu tercermin pada hak dan kewajiban. Dalam mengatur hubungan-hubungan hukum itu caranya beraneka ragam. Kadang-kadang hanya dirumuskan kewajiban-kewajiban seperti pada hukum pidana yang sebagian besar peraturan-peraturannya terdiri dari kewajiban-kewajiban. Sebaliknya, seiring juga hukum merumuskan peristiwa-peristiwa tertentu yang merupakan syarat timbulnya hubungan-hubungan hukum (Sudikno Mertokusumo, 2010: $50)$.

Kehadiran hukum dalam masyarakat di antaranya adalah untuk mengintegrasikan dan mengkoordinasikan kepentingan-kepentingan yang bisa bertubrukan satu sama lain itu oleh hukum diintegrasikan sedemikian rupa sehingga tubrukan-tubrukan itu bisa ditekan sekecil-kecilnya. Pengorganisasian kepentingan-kepentingan itu dilakukan dengan membatasi dan melindungi kepentingan-kepentingan tersebut. Memang, dalam suatu lalu lintas kepentingan, perlindungan terhadap kepentingan-kepentingan tertentu hanya dapat dilakukan dengan cara membatasi kepentingan dilain pihak (Satjipto Rahardjo, 2006: 53). 
Berbicara mengenai sistem hukum, walaupun secara singkat, hendaknya harus diketahui terlebih dahulu arti dari sistem itu. Dalam suatu sistem terdapat ciri-ciri tertentu, yaitu terdiri dari komponenkomponen yang satu sama lain berhubungan ketergantungan dan dalam keutuhan organisasi yang teratur serta terintegrasi (R. Abdoel Djamal. 2001: 65).

Sistem peradilan pidana lebih diarahkan pada masalah pemidanaan. Mengenai untuk apa pemidanaan dilakukan, banyak teorinya tetapi teori-teori pemidanaan cenderung mengerucut pada dua pendekatan dasar: Reductionist dan Retributivist. Pendekatan Reduksi (The reductionist approach) melihat pemidanaan sebagai suatu alat kontrol sosial yang dirancang untuk mengurangi perbuatan anti sosial (instrument of social control designed to reduce antisocial activity), dimana umumnya hal itu dilakukan melalui pengisolasian dan detterence, disamping itu juga bisa dilakukan melalui rehabilitasi dan pendidikan. Sedangkan pendekatan pembalasan (The retributivist approach) memandang pemidanaan sebagai suatu tanggapan moral yang pantas dan/atau diperlukan terhadap tindakan terlarang. Di antara berbagai jenis pemidanaan, pidana penjara (pemasyarakatan) merupakan yang paling populer, dan jumlah penghuninya terus meningkat.

Lembaga permasyarakatan diharapkan menjalankan sistem pemasyarakatan agar terpidana narkotika (atau yang dikenal sebagai warga binaan pemasyarakatan/WBP) menyadari kesalahan, memperbaiki diri, tidak mengulangi tindak pidana sehingga, dapat diterima kembali oleh lingkungan masyarakat, dapat aktif berperan dalam pembangunan, dan dapat hidup secara wajar sebagai warga yang baik dan bertanggung jawab, dan tidak menjadi residivis.

Sistem Pemasyarakatan adalah suatu tatanan mengenai arah dan batas serta cara pembinaan Warga Binaan Pemasyarakatan (WBP) berdasarkan Pancasila yang dilaksanakan secara terpadu antara pembina, yang dibina, dan masyarakat untuk meningkatkan kualitas WBP agar menyadari kesalahan, memperbaiki diri, dan tidak mengulangi tindak pidana sehingga dapat diterima kembali oleh lingkungan masyarakat, dapat aktif berperan dalam pembangunan, dan dapat hidup secara wajar sebagai warga yang baik dan bertanggungjawab.

Berdasarkan Pasal 54 Kitab Undang-Undang Hukum Pidana (KUHP) dinyatakan bahwa pemidanaan antara lain bertujuan untuk memasyarakatkan terpidana dengan mengadakan pembinaan sehingga menjadi orang baik dan berguna. Hal ini dicapai dengan jalan Rehabilitasi dan Resosialisasi, memasyarakatkan terpidana, dengan melakukan pembinaan sehingga menjadi orang yang baik dan berguna. Supaya mereka bisa kembali ke masyarakat (itulah sebabnya disebut LP singkatan dari Lembaga Pemasyarakatan). Dalam perspektif ini mereka bukan dipandang sebagai penjahat, hanya orang yang tersesat, sehingga masih ada waktu untuk bertobat.

Lembaga Pemasyarakatan sebagai gerbang pelaksana pembinaan Terpidana Narkotika sangat berperan dalam "memasyarakatkan kembali" atau sejatinya menjadi tempat pembinaan bagi narapidana untuk dipersiapkan kembali ke masyarakat setelah bebas dari masa tahanan. Karena yang menjadi tujuan lembaga ini adalah perubahan sifat, cara berfikir serta perilaku, proses interaksi edukatif harus dibangun. Namun dalam perkembangannya Lembaga Pemasyarakatan selalu didatangkan masalah dari tahun ke tahun khususnya pada Lembaga Pemasyarakatan Narkotika.

Pembinaan pada narapidana narkotika Lembaga Permasyarakatan melakukan program pembinaan terapi rehabilitasi medis maupun sosial. Berdasarkan Keputusan Menteri Kehakiman RI Nomor: M.02PK.04.10 tanggal 10 April 1990 tentang Pola Pembinaan Narapidana dan Tahanan, dan kemudian diperkuat dengan Edaran Direktur Jenderal Pemasyarakatan No. E.55. PK.04 tahun 2005 tanggal 27 Juni 2005 tentang startegi penanggulangan HIV/AIDS dan penyalahgunaan Narkoba di dalam Lembaga Pemasyarakatan dan Rumah Tahanan di Indonesia Tahun 2005-2009.

Rehabilitasi diartikan sebagai pengobatan dan sebagai pemulihan. Kebijakan narkotika menekankan kepada bentuk-bentuk pengobatan untuk membebaskan pecandu dari ketergantungan narkotika. Ada beberapa syarat yang perlu dipenuhi sebelum seseorang dapat menjalani program rehabilitasi narkoba tersebut, antara lain kelengkapan surat, hasil tes urine, hasil pemeriksaan medis secara keseluruhan, kesediaan orang tua atau wali yang dapat mewakili, dan lain-lainnya. Namun pada kenyataannya penanganan para penyalahgunaan narkotika di Indonesia masih rancu. Para pecandu narkotika yang merupakan korban pada akhirnya banyak divonis pidana penjara dan ditempatkan dalam Lembaga Pemasyarakatan (LAPAS), yang mana dalam lapas tersebut para pecandu narkotika disatukan dengan para bandar, sindikat, dan pengedar gelap narkoba. Padahal dengan adanya strategi Pencegahan dan Pemberantasan Penyalahgunaan dan Peredaran Gelap Narkotika (P4GN) menyebutkan pecandu dan korban penyalahgunaan narkotika tersebut diberikan perawatan berupa rehabilitasi medis dan rehabilitasi sosial yang dapat memulihkan pecandu. Namun seperti diketahui masih banyak peredaran narkotika di dalam Lapas, ini membuktikan belum seriusnya penegak hukum dalam merehabilitasi para narapidana tersebut. 
Ini terjadi terhadap pembuatan Peraturan Perundang undangan yang merupakan pesanan elit politik, negara asing maupun Lembaga Keuangan Internasional. Disini Peraturan Perundang undangan dibuat sebagai komoditas (Imron Rosyadi, 2007: 80).

Dalam hal lembaga pemasyarakatan dalam menjalankan rehabilitasi terhadap narapidana narkotika, sehingga yang menjadi fokus permasalahn dalam penulisan ini adalah Bagaimana rehabilitasi terhadap pelaku tindak pidana penyalahgunaan narkotika yang diselenggarakan Lembaga Pemasyarakatan?, Bagaimana kebijakan Lembaga Pemasyarakatan dalam pelaksanaan rehabilitasi terhadap pelaku tindak pidana penyalahgunaan narkotika?, dengan harapan tulisan ini dapat bermanfaat baik secara teori maupun praktis bagi khalayak luas dalam hal lembaga pemasyarakatan dalam menjalankan rehabilitasi terhadap narapidana narkotika.

\section{METODE PENELITIAN}

Penulisan ini menggunakan metode penelitian hukum yuridis normatif (normatif research), yaitu penelitian hukum yang dilakukan dengan cara meneliti bahan pustaka atau data skunder (Seokanto dan Sri Muji, 2003: 15). Spesifikasi penelitian dalam penulisan ini berupa penelitian deskriptif analistis. Deskriptif adalah menunjukan komparasi atau hubungan seperangkat data dengan seperangkat data yang lain, dan maksudnya adalah untuk memberikan gambaran, menelaah, menjelaskan dan menganalisis (Soekanto, 1996: 63).

Sesuai jenis dan sifat penelitiannya, maka sumber data yang digunakan dalam penulisan ini adalah data skunder yang terdiri dari bahan hukum primer berupa; berupa; UU No. 35 tahun 2009 tentang narkotika, Surat Edaran Mahkamah Agung No. 4 tahun 2010, Undang-Undang Nomor 22 Tahun 1997 tentang Narkotika, Undang-Undang Nomor 12 Tahun 1995 tentang Pemasyarakatan, Keputusan Menteri Kehakiman RI Nomor: M.02-PK.04.10 tanggal 10 April 1990 tentang Pola Pembinaan Narapidana dan Tahanan, Undang-Undang, Nomor 12 Tahun 1995 tentang Pemasyarakatan, Undang-Undang Dasar UUD 1945. Bahan hukum sekunder terdiri dari buku-buku, jurnal ilmiah, makalah dan artikel ilmiah yang dapat memberi penjelasan tentang bahan hukum primer. Bahan hukum tersier; berupa Kamus Besar Bahasa Indonesia (KBBI) dan lain sebagainya dalam menemukan defenisi dari istilah-istilah dalam membahas tentang lembaga pemasyarakatan dalam menjalankan rehabilitasi terhadap narapidana narkotika.

Prosedur yang digunakan untuk mengumpulkan data dalam penilitian ini berupa dokumentasi yaitu pedoman yang digunakan berupa catatan atau kutipan, penelusuran literatur hukum, buku-buku dan lainnya yang bertalian dengan identifikasi masalah dalam penilitian ini dengan cara offline maupun online. Analisa bahan hukum dilakukan dengan menggunakan metode analisa konten (centent analysis method) yang dilakukan dengan menguraikan materi peristiwa hukum atau produk hukum secara rinci guna memudahkan interpretasi dalam pembahasan (Marzuki, 2011: 171).

\section{HASIL dan PEMBAHASAN PENELITIAN}

1. Rehabilitasi Terhadap Narapidana Narkotika Yang Diselenggarakan Lembaga Pemasyarakatan.

a. Dasar Hukum Lembaga Pemasyarakatan dalam melaksanakan Rehabilitasi.

Narkotika secara etimologis berasal dari bahasa Inggris narcoseatau narcoisyang berarti menidurkan dan pembiusan. Kata narkotika berasal dari bahasa Yunani yaitu narkeyang berarti terbius sehingga tidak merasakan apa-apa. (Hari sasangka, 2003: 35). Mengenai untuk apa pemidanaan dilakukan, banyak teorinya tetapi teori-teori pemidanaan cenderung mengerucut pada dua pendekatan dasar: Reductionist dan Retributivist. Pendekatan Reduksi (The reductionist approach) melihat pemidanaan sebagai suatu alat kontrol sosial yang dirancang untuk mengurangi perbuatan anti sosial (instrument of social control designed to reduce antisocial activity), dimana umumnya hal itu dilakukan melalui pengisolasian dan detterence, disamping itu juga bisa dilakukan melalui rehabilitasi dan pendidikan. Sedangkan pendekatan pembalasan (The retributivist approach) memandang pemidanaan sebagai suatu moral yang pantas dan/atau diperlukan terhadap tindakan terlarang. (Topo Santoso, 2012: 213).

Undang-Undang Nomor 12 Tahun 1995 tentang Pemasyarakatan Pasal 6 ayat (1) secara jelas dan tegas menetapkan dua lembaga dalam sistem pembinaan/ pemasyarakatan yaitu Lembaga Pemasyarakatan (LAPAS) dan balai Pemasyarakan (BAPAS). Kedua lembaga tersebut tidak sama fungsinya. Tugas LAPAS adalah melakukan pembinaan terhadap warga binaan pemasyarakatan, sedangkan BAPAS, bertugas melaksanakan bimbingan terhadap warga binaan pemasyarakatan.

Dalam rangka melaksanakan tugas pembinaan terhadap warga binaan kemasyarakan, Kepala LAPAS memiliki tanggung jawab, kewajiban dan wewenang sebagai berikut:

1) Berdasarkan Pasal 46 Undang-Undang Pemasyarakatan, Kepala LAPAS bertanggungjawab atas keamanan dan ketertiban di LAPAS yang di pimpinnya. Oleh karena itu Pasal 48 menegaskan 
bahwa pada saat menjalankan tugasnya, petugas LAPAS, diperlengkapi dengan sejata api dan sarana keamanan yang lain.

2) Berdasarkan Pasal 47 ayat (3) Undang-Undang Pemasyarakatan dikemukakan bahawa, petugas pemasyarakatan dalam memberikan tindakan disiplin sebagaimana dimaksud ayat (1) wajib :

a) Memperlakukan warga binaan pemasyarakatan secara adil dan tidak bertindak sewenangwenang.

b) Mendasarkan tindakannya pada peraturan tata tertib LAPAS.

3) Berdasarkan pada Pasal 47 ayat (1) UU Pemasyarakatan, Kepala LAPAS berwenang memberikan tindakan disiplin atau menjatuhkan hukuman disiplin terhadap warga binaannya yang melanggar peraturan keamanan dan ketertiban di lingkungan LAPAS yang dipimpinnya. Pasal 47 ayat (2) menjelaskan bahwa, jenis hukuman disiplin tersebut berupa:

a) Tutupan sunyi paling lama 6 (enam) hari bagi narapidana atau anakn pidana, dan atau

b) Menunda atau meniadakan hak tertentu untuk jangka waktu tertentu sesuai dengan peraturan perundang-undangan yang berlaku. ketentuan mengenai rehabilitasi terhadap pecandu narkotika diatur di dalam Pasal 45 dan 47 Undang-Undang Nomor 22 Tahun 1997, Pasal 45: "Pecandu narkotika wajib menjalani pengobatan dan/atau perawatan".

Pasal 47 Undang-Undang Nomor 22 Tahun 1997, Menyebutkan bahwa Hakim yang memeriksa perkara pecandu narkotika dapat:

a) Memutuskan untuk memerintahkan yang bersangkutan menjalani pengobatan dan/atau perawatan, apabila pecandu narkotika tersebut terbukti bersalah melakukan tindak pidana narkotika; atau

b) Menetapkan untuk memerintahkan yang bersangkutan menjalani pengobatan dan/atau perawatan, apabila pecandu narkotika tersebut tidak terbukti bersalah melakukan tindak pidana narkotika.

Masa menjalani pengobatan dan/atau perawatan bagi pecandu narkotika sebagaimana dimaksud dalam ayat (1) huruf a, diperhitungkan sebagai masa menjalani hukuman. Kemudian di dalam Surat Edaran Mahkamah Agung Nomor 07 Tahun 2009 menghimbau bagi para hakim yang memeriksa perkara pecandu narkotika untuk menerapkan ketentuan Pasal 47 Undang-Undang Nomor 22 Tahun 1997 tentang Narkotika yang berisikan mengenai tindakan rehabilitasi yang diperintahkan untuk dijalani oleh pecandu narkotika.

Hal tersebut berdasarkan pertimbangan bahwa sebahagian besar narapidana dan tahanan kasus narkoba adalah termasuk kategori pemakai atau bahkan sebagai korban yang jika dilihat dari aspek kesehatan mereka sesungguhnya orangorang yang menderita sakit, oleh karena itu memenjarakan yang bersangkutan bukanlah langkah yang tepat karena telah mengabaikan kepentingan perawatan dan pengobatan.

Dilihat dari segi kondisi Lembaga Pemasyarakatan pada saat ini tidak mendukung, karena dampak negatif keterpengaruhan oleh perilaku kriminal lainnya dapat semakin memperburuk kondisi kejiwaan, kesehatan yang diderita para narapidana narkotika akan semakin berat. Surat Edaran Mahkamah Agung (SEMA) yaitu suatu bentuk edaran dari Mahkamah Agung yang berupa himbauan Mahkamah Agung keseluruh jajaran peradilan yang isinya merupakan petunjuk teknis dalam penyelenggaraan peradilan yang lebih bersifat admnistrasi.

Penerapan pemidanaan sebagaimana dimaksud pada Pasal 47 Undang- Undang Nomor 22 Tahun 1997 hanya dapat dijatuhkan pada klasifikasi tindak pidana seperti:

a) Terdakwa pada saat ditangkap oleh penyidik dalam kondisi tertangkap tangan;

b) Pada saat tertangkap tangan sesuai butir di atas, ditemukan barang bukti satu kali pakai.

c) Surat keterangan uji laboratories positif menggunakan narkoba berdasarkan permintaan penyidik;

d) Bukan residivis kasus narkoba;

e) Perlu surat keterangan dari dokter jiwa/psikiater yang ditunjuk oleh hakim;

f) Tidak terdapat bukti bahwa yang bersangkutan merangkap menjadi pengedar/produsen gelap narkoba.

Kemudian pada Tahun 2009 dikeluarkan Undang-Undang Nomor 35 Tahun 2009 yang juga mengatur ketentuan mengenai putusan memerintahkan untuk menjalani rehabiltasi bagi pengguna narkotika dalam Pasal 54 dan 103

Pasal 54 menyebutkan bahwa pecandu narkotika dan korban penyalahgunaan narkotika wajib menjalani rehabilitasi medis dan rehabilitasi sosial. Pasal 103 Ayat (1) Undang-Undang Nomor 35 Tahun 2009 menyebutkan bahwa Hakim yang memeriksa perkara pecandu narkotika dapat memutuskan untuk memerintahkan yang bersangkutan menjalani pengobatan dan/atau perawatan, apabila pecandu narkotika tersebut terbukti bersalah melakukan tindak pidana narkotika; atau menetapkan untuk memerintahkan 
yang bersangkutan menjalani pengobatan dan/atau perawatan, apabila pecandu narkotika tersebut tidak terbukti bersalah melakukan tindak pidana narkotika.

Masa menjalani pengobatan dan/atau perawatan bagi pecandu narkotika sebagaimana dimaksud dalam ayat (1) huruf a, diperhitungkan sebagai masa menjalani hukuman. Adapun dengan mulai berlakunya Undang-Undang No 35 Tahun 2009 maka terhadap Korban penyalahgunaan Narkoba, hakim dapat menjatuhkan putusan untuk menjalani proses Terapi Rehabilitasi baik medis atau sosial di Rumah Sakit/lembaga yang ditunjuk oleh Pemerintah. Kondisi ini merupakan langkah maju mengingat selama ini terhadap korban penyalahgunaan Narkoba dihukum dengan pidana penjara dan menjadi beban Lapas/Rutan sementara penanganan pihak Lapas/Rutan sampai saat ini masih belum maksimal. Masih sangat banyak kendala dilapangan yang belum mendapatkan jalan pemecahannya. Seperti masih belum diatur dengan jelas mengenai tanggung jawab terhadap keamanan selama korban penyalahguna menjalani masa Terapi Rehabilitasi di Rumah sakit atau di Panti Rehabilitasi serta penanggungjawab biaya selama menjalani terapi tersebut.

Mekanisme pelaksanaan putusan hakimpun masih perlu petunjuk lebih lanjut dengan Peraturan Pemerintah, khususnya terhadap korban penyalahgunaan yang menjalani proses Terapi Rehabilitasi. Untuk sementara diperlukan adanya regulasi terpadu antara para pemangku kepentingan untuk penanganan masalah pelaksanaan penempatan korban penyalahguna di tempat Rehabilitasi.

Lembaga Pemasyarakatan diharapkan dapat mendukung penerapan sanksi rehabilitasi terhadap pecandu narkoba Hal itu akan mengurangi tingkat kepadatan penghuni lapas yang sudah di luar batas kewajaran. Sanksi tindakan berupa rehabilitasi terhadap pecandu narkotika ini lebih tepat dan efektif dibanding dengan sanksi pidana penjara. Hal ini juga dapat di buktikan dengan adanya fakta bahwa kasus penyalahgunaan sampai saat ini cenderung meningkat. Di sebagian besar wilayah di Indonesia, mengalami peningkatan jumlah kasus penyalahgunaan narkotika.

Untuk itu, berdasarkan Pasal 5 Undang-Undang Nomor 12 Tahun 1995 tentang Pemasyarakatan, asas-asas pembinaan pemasyarakatan meliputi :

a) Asas Pengayoman

b) Asas Persamaan Perlakuan dan Pelayanan

c) Asas Pendidikan

d) Asas Pembimbingan

e) Asas Penghormatan Harkat dan Martabat Manusia

f) Asas Kehilangan Kemerdekaan MerupakanSatu-satunya Penderitaan

g) Asas Terjaminnya Hak untuk Tetap Berhubungan Baik dengan Keluarga dan Orang-orang Tertentu (Nashriani, 2012: 155).

Dipidana penjaranya para pecandu narkotika, tidak membuat mereka lantas meninggalkan penyalahgunaan narkotika tersebut. Sebab pada umumnya sistem pembinaan terhadap pecandu narkotika yang menjalani masa hukumannya di Lembaga Pemasyarakatan tidak ada bedanya dengan sistem pembinaan yang dilakukan terhadap para narapidana kasus lainnya. Padahal mereka sangat membutuhkan suatu pengobatan dan/atau perawatan khusus untuk memulihkan kondisi kesehatan mereka yang telah rusak akibat penggunaan narkotika dan kelak tidak lagi menggunakannya. Memasukkan pecandu narkotika ke dalam penjara bukanlah keputusan yang tepat, sebab hal ini berarti tujuan pemidanaan yang diterapkan adalah tujuan pembalasan. Sedangkan bagi pecandu narkotika, tujuan pemidanaan yang harus diwujudkan adalah "treatment" mengingat kondisinya yang memerlukan pengobatan dan/atau perawatan.

Tujuan pembuatan peraturan perundang undangan adalah untuk ketertiban dan legitimasi yang juga mempertimbangkan kompetensi. Secara legitimasi, kita harus akui disamping sebagai ketahanan sosial sebagai tujuan negara (daerah daerah tertentu), tetapi juga sudah mencapai legistimasi prosedural, walaupun belum kepada subtantif (Sabian Utsman, 2010:37). Narapidana bukan saja sebagai objek, melainkan juga subjek yang tidak berbeda dari manusia lainnya yang sewaktu-waktu dapat melakukan kesalahan atau kekhilapan yang dapat dikenakan pidana, sehingga harus diberantas atau dimusnahkan. Sementara itu, yang harus diberantas adalah faktor-faktor yang dapat menyebabkan narapidana tersebut berbuat hal-hal yang bertentangan dengan hukum, kesusilaan, agama, atau kewajiban-kewajiban sosial lainnya yang dapat dikenakan pidana (C.I. Harsono, 1995: 18-19).

2. Kebijakan Lembaga Pemasyarakatan Dalam Pelaksanaan Rehabilitasi Terhadap Pelaku Tindak Pidana Penyalahgunaan Narkotika

a. Proses dan Tata Cara Rehabilitasi di Lembaga Pemasyarakatan

Masalah penegakan hukum sebenarnya terletak pada faktor faktor tersebut yang mungkin mempengaruhinya. Faktor faktor tersebut mempunyai arti yang netral, sehingga 5 dampak posif atau negatifnya terletaknya pada isi faktor faktor tersebut. Faktor faktor tersebut, adalah sebagai berikut : Faktor hukumnya sendiri, Faktor penegak hukum, yakni pihak pihak yang membentuk maupun menerapkan hukum, Faktor sarana atau fasilitas yang mendukung penegakan hukum, Faktor masyarakat, 
yakni lingkungan di mana hukum tersebut berlaku atau diterapkan dan Faktor kebudayaaan, yakni sebagai hasil karya, cipta, dan rasa yang didasarkan pada karsa manusia di dalam pergaulan hidup (Satjipto Rahardjo, 2009: 8).

Lembaga Pemasyarakatan bukan tempat untuk pembalasan dendam para narapidana yang telah melakukan kesalahan (Gatot Supramo, 2000: 155). Dalam Lembaga Pemasyarakatan, warga binaan pemasyarakatan juga mendapat pembinaan yang diselenggarakan berdasarkan Pancasila dengan menanamkan jiwa kekeluargaan, keterampilan, pendidikan dan kerohanian. (Darwin, 1997: 69).

Dalam pusat rehabilitasi, pecandu narkotika mendapatkan pengobatan dan/atau perawatan khusus terhadap gangguan kesehatan akibat dari penyalahgunaan narkotika dan menghilangkan rasa ketergantungan. Seperti yang dilakukan di Lapas Narkotika Kelas III Langkat, pertama-tama dilakukan detoksifikasi untuk mengeluarkan racun-racun yang berada di dalam tubuhnya dengan cara mandi uap dengan menggunakan rempah-rempah tradisional kemudian diberikan terapi untuk menghilangkan ketergantungannya. Dan kemudian diberikan konseling dan bimbingan rohani, bahkan telah ada wacana mengenai akan diterapkannya suatu program after rehabilitation, yaitu berupa program yang bertujuan agar mantan pecandu yang telah sembuh memiliki kepercayaan diri untuk kembali bergaul ke tengahtengah masyarakat (Skripsi Mahasiswa Fakultas Hukum: UMSU).

Hal tersebut tidak didapatkan oleh pecandu narkotika apabila ia dimasukkan ke dalam Lembaga Pemasyarakatan biasa. Padahal pengobatan dan/atau perawatan tersebut sangat dibutuhkan oleh para pecandu. Berdasarkan hal tersebut di atas, mengingat kembali bahwa pembaharuan hukum pidana merupakan bagian dari kebijakan kriminal, maka kebijakan kriminal dalam penentuan sanksi yang tertuang di dalam ketentuan mengenai pecandu narkotika, dengan dikeluarkannya undang-undang yang baru, menunjukkan adanya suatu langkah pembaharuan hukum pidana nasional sebab, terjadinya perubahan dari konsep yang lama ke yang baru yang semakin menunjukkan adanya pergeseran dari tujuan menjatuhkan sanksi pidana terhadap pecandu narkotika menjadi lebih cenderung menjatuhkan sanksi tindakan berupa rehabilitasi.

Pembinaan adalah kegiatan untuk meningkatkan kualitas ketaqwaan kepada Tuhan Yang Maha Esa, intelektual, sikap dan perilaku, profesional, kesehatan jasmani dan rohani Narapidana dan Anak Didik Pemasyarakatan. Pada saat ini pola pembinaan yang dianut dalam sistem pemasyarakatan adalah berdasarkan Surat Keputusan Menteri Kehakiman RI. No. M.02-PK.04.10 Tahun 1990. Istilah pola menunjukkan sesuatu yang dapat digunakan sebagai model, acuan, pegangan atau pedoman untuk membuat atau menyusun sesuatu. Dengan demikian dikatakan bahwa pola pembinaan yang dimaksud di sini adalah acuan, pegangan atau pedoman untuk membuat atau menyusun sistem pembinaan narapidana.

Dalam Surat Keputusan Menteri Kehakiman tersebut tercakup segala hal yang berhubungan dengan pembinaan narapidana, yaitu tentang pengertian, tujuan, kebijaksanaan, faktor-faktor yang mempengaruhi pembinaan, kemudian metode dan pelaksanaan pembinaan, sarana pembinaan dan pelaksanaan pengawasan pembinaan.

Menurut SK. Menteri Kehakiman tersebut, pengertian pemasyarakatan merupakan bagian dari sistem peradilan pidana dari segi pelayanan tahanan, pembinaan narapidana, anak negara dan bimbingan klien pemasyarakatan yang dilaksanakan secara terpadu (dilaksanakan bersama-sama dengan semua aparat penegak hukum), dengan tujuan agar mereka, setelah menjalani pidananya dapat kembali menjadi warga masyarakat yang baik.

Sedangkan pembinaan narapidana dan anak didik ialah semua usaha yang ditujukan untuk memperbaiki dan meningkatkan akhlak (budi pekerti) para narapidana dan anak didik yang ada di dalam lembaga pemasyarakatan (intramural treatment). Pemasyarakatan adalah suatu proses pembinaan narapidana yang sering disebut therapeutic process. Dengan demikian jelaslah bahwa membina narapidana itu sama artinya dengan menyembuhkan seseorang yang sementara tersesat hidupnya karena adanya kelemahan-kelemahan yang dimilikinya.

Secara umum pembinaan narapidana di Lapas Narkotika bertujuan agar mereka dapat menjadi manusia seutuhnya sebagaimana yang telah menjadi arah pembangunan nasional melalui jalur pendekatan:

1) Memantapkan iman (ketahanan mental) mereka;

2) Membina mereka agar mampu berintegrasi secara wajar di dalam kehidupan kelompok selama dalam lembaga pemasyarakatan dan kehidupan yang lebih luas (masyarakat) setelah selesai menjalani masa pidananya (Skripsi Mahasiswa Fakultas Hukum: UMSU).

Hal ini tentu merupakan suatu tantangan yang sangat berat bagi Lembaga Pemasyarakatan mengingat di satu sisi lembaga Pemasyarakatan diharapkan dapat memenuhi perannya untuk melakukan rehabilitasi terhadap pelaku penyalahgunaan Narkoba pada tingkat pengguna atau pecandu, dan di sisi lain sarana dan prasarana yang dimiliki LP belum sepenuhnya mendukung. Proses rehabilitasi terhadap para pecandu Narkoba jelas jauh berbeda dengan tahapan rehabilitasi yang harus dijalani oleh Narapidana 
biasa. Proses rehabilitasi terhadap pecandu Narkoba harus melalui prosedur treatment tertentu yang memerlukan sarana dan pra sarana yang khusus.

Narapidana pelaku tindak pidana narkotika dan psikotropika dalam pembinaan mengalami beberapa proses yang berkaitan dengan perubahan sikap mental, yaitu:

\section{1) Proses Ketergantungan}

Adiksi atau ketergantungan terhadap narkoba merupakan suatu kondisi di mana seseorang mengalami ketergantungan secara fisik dan psikologis terhadap suatu zat adiktif dan menunjukkan tandatanda sebagai berikut:

a) Adanya proses toleransi, individu membutuhkan zat yang dimaksud dalam jumlah yang semakin lama semakin besar, untuk dapat mencapai keadaan fisik dan psikologis seperti pada awal mereka merasakannya.

b) Adanya gejala putus zat (withdrawal syndrome) yaitu individu akan merasakan gejala-gejala fisik dan psikologis yang tidak nyaman apabila penggunaan zatnya dihentikan.

Rogers \& McMillins mengatakan bahwa adiksi dapat digolongkan sebagai suatu penyakit yang memiliki kriteria sebagai berikut:

a) Penyakit primer: seringkali tidak diperlukan suatu kondisi awal khusus untuk dapat menyebabkan seseorang menjadi pecandu.

b) Kronis: merupakan kondisi yang berulang kali kambuh

c) Progresif: kondisi fisik dan psikologis penderita semakin lama akan mengarah pada keadaan yang memburuk.

d) Potensial fatal: dapat mengakibatkan kematian atau mengalami komplikasi medis, psikologis dan sosial yang serius.

\section{2) Proses Perubahan}

Memotivasi individu yang mengalami ketergantungan pada zat adiktif untuk bisa menghentikan pola penggunaan zatnya bukanlah hal yang mudah. Prochaska \& DiClemente mengatakan bahwa ada tahap-tahap perubahan yang dialami oleh seorang pecandu yang mempengaruhi proses pemulihannya, yaitu:

a) Precontemplation adalah tahap di mana pecandu umumnya belum mau mengakui bahwa perilaku penggunaan zatnya merugikan diri sendiri, keluarga dan lingkungannya. Pada tahap ini seorang pecandu akan menampilkan mekanisme pertahanan diri agar mereka dapat tetap mempertahankan pola ketergantungan zatnya. Jenis mekanisme pertahanan diri paling sering muncul adalah penyangkalan (denial) di mana pecandu selalu "mengelak" atas kenyataan kenyataan negatif yang di timbulkan akibat penggunaan zatnya. Jenis mekanisme pertahanan diri lain adalah mencari pembenaran rasionalisme), di mana pecandu akan selalu berdalih untuk melindungi perilaku ketergantungannya.

b) Contemplation adalah tahap di mana pecandu mulai menyadari bahwa perilaku renggunaan zatnya merugikan diri sendiri, keluarga dan lingkungannya, tetapi sering merasa ragu-ragu (ambivalen) untuk menjalani proses pemulihan. Proses wawancara motivasional sangat rnenentukan apakah pecandu kembali pada tahap precontemplation diatas atau justru semakin termotivasi untuk pulih.

c) Preparation adalah tahap di mana individu mempersiapkan diri untuk berhenti dari pola penggunaan zatnya. Umumnya yang bersangkutan mulai mengubah pola pikirnya yang dianggap dapat membantu usahanya untuk dapat bebas dari zat.

d) Action adalah tahap di mana seorang pecandu dengan kesadaran sendiri mencari pertolongan untuk membantu pemulihannya.

e) Maintenance adalah tahap di mana seorang pecandu berusaha untuk mempertahankan keadaan bebas zatnya (abstinensia).

f) Relapse adalah tahap di mana seorang pecandu kembali pada pola perilaku penggunaan zatnya yang lama sesudah ia mengalami keadaan bebas zat.

\section{3) Proses Pemulihan}

Proses pemulihan merupakan proses yang harus dijalani seumur hidup seorang pecandu (long life process). Proses pemulihan itu sendiri melewati 6 (enam) periode, yaitu:

a) Periode pra perawatan (pretreatment)

Pecandu akan mencoba dengan berbagai cara untuk mengatasi proses ketergantungan fisik dan belajar untuk mengakui bahwa dia tidak bisa mengontrol perilaku penggunaan zatnya.

b) Periode stabilitasi (stabilization) 
Pecandu akan belajar untuk tidak menggunakan zat, membuat kondisi fisik lebih stabil dari gejala putus zat, belajar untuk mengatasi tekanan sosial dan masalah

c) Periode pemulihan awal (early recovery)

Pecandu pada tahap ini membangun pola pikir mengapa ia tidak dapat lagi menggunakan zat adiktif dan mulai untuk membangun sistem nilai personal.

d) Periode pemulihan tengah (middle recovery)

Pecandu memasuki masa transisi di mana ia mengalami hambatan dalam ketrampilan bersosialisasi, namun ia sampai pada periode konsolidasi diri.

e) Periode pemulihan lanjut (late recovery)

Pada saat ini diharapkan pecandu sudah memiliki kesadaran spiritual, memiliki prinsip hidup yang pasti dan menemukan keinginan serta semangat hidup

f) Periode pemeliharaan (maintenance).

Pecandu diharapkan mempertahankan kondisi bebas zatnya (sober) dan mencoba hidup kembali sebagaimana masyarakat pada umumnya dengan sistem nilai hidup mereka yang baru.

Setelah proses tersebut dilalui, bagi para pecandu yang telah mulai tersembuhkan tersebut masih harus tetap dijaga dari kemungkinan kambuh, antara lain terkait dengan lingkungan dimana dia berada, hendaknya steril dari segala bentuk pengaruh yang dapat menyebabkannya kembali mengalami kecanduan. Penyebab dari kekambuhan diantaranya disebabkan karena 5 (lima) faktor:

a) Kepribadian yang adiktif (addictive personality), misalnya: manipulatif, malas, bohong, detensif, impulsif, kompulsif, dan lain-lain.

b) Sistem kepercayaan yang salah (faulty believe system), seperti: rasionalisasi terhadap zat adiktif, mengganti zat adiktif yang biasa dipakai dengan yang lain (dari heroin berganti ke ganja).

c) Rujukan lama (old reference) adalah apabila penderita kembali pada pola perilaku lamanya, seperti misalnya Kembali ke tempat di mana ia biasa mondapatkan zat adiktif

d) Kemampuan bertahan yang tidak terpenuhi (inadequate coping skills), yaitu kurangnya kemampuan untuk mengatasi masalah dan tekanan.

e) Kebutuhan spiritual dan emosional yang tidak terpenuhi. Misalnya : terlalu sensitif, hilang kepercayaan terhadap Tuhan Yang Maha Esa, dan lain-lain.

\section{4) Penentuan Diagnosis Ketergantungan}

a) Dokter lembaga pemasyarakatan melakukan pemeriksaan darah dan urin Narapidana/Anak Didik Pemasyarakatan untuk mengetahui sejak awal penyakit yang diderita Narapidana/Anak Didik Pemasyarakatan;

b) Pemeriksaan fisik atau gejala-gejala klinis maupun pemeriksaan penunjang apabila diperlukan, misalnya pemeriksaan jantung, paru-paru hepatitis, HIV/AIDS, dan penyakit menular lainnya yang disebabkan dari narkotika yang digunakan;

c) Narapidana/Anak Didik Pemasyarakatan yang dalam keadaan putus zat dengan komplikasi (jantung, paru-paru hepatitis, HIV/AIDS, dan penyakit lainnya) harus dirujuk ke Rumah Sakit.

\section{5) Tahap Penyembuhan Rehabilitasi}

1) Narapidana/Anak Didik Pemasyarakatan baru pada tahap awal masih diasumsikan dalam kondisi ketergantungan narkotika, harus dihilangkan ketergantungannya terlebih dahulu dengan cara cold turkey yang dilakukan dan ditentukan oleh dokter Lapas;

2) Narapidana/Anak Didik Pemasyarakatan dalam pemeriksaan kesehatan dan fisik tidak ditemukan penyakit yang berbahaya dan menular dapat ditempatkan pada program selanjutnya; (Skripsi Mahasiswa Fakultas Hukum: UMSU).

Pelaksanaan cold turkey maupun ditoksifikasi dilakukan diruang khusus yang terisolasi dari pengaruh lingkungan luar lainnya.

\section{6) Pembinaan Kepribadian}

Pembinaan kesadaran mental dan fisik (Skripsi Mahasiswa Fakultas Hukum: UMSU).

a) Kegiatan bertujuan menguatkan jasmani dan rohani Narapidana/Anak Didik Pemasyarakatan melalui pendidikan/penyuluhan agama, pembinaan psikis, pembinaan olahraga, dan lain-lain;

b) Pelaksanaan pembinaan kesadaran mental dan fisik dilakukan oleh Subsi Bimkemaswat;

c) Untuk melaksanakan kegiatan pembinaan kesadaran mental, dan fisik disusun rencana kegiatan yang mencakup: materi, waktu, tempat, peserta, pembawa materi dan sebagainya;

d) Pembinaan kesadaran mental dan fisik dapat dilaksanakan sendiri oleh pihak lembaga pemasyarakatan dengan mengundang pembawa materi dari instansi terkait atau masyarakat. 
Pembinaan berbangsa dan bernegara, serta kesadaran hukum: (Skripsi Mahasiswa Fakultas Hukum: UMSU).

a) Pelaksanaan pembinaan berbangsa dan bernegara serta kesadaran hukum dilakukan dengan metode: ceramah, diskusi, temu wicara atau simulasi;

b) Tanggung jawab pelaksanaan pembinaan berbangsa dan bernegara serta kesadaran hukum dilakukan oleh Kasi Binadik/Subsi Bimaswat;

c) Untuk melaksanakan pembinaan berbangsa dan bernegara serta kesadaran hukum disusun rencana kegiatan yang mencakup : materi, waktu, tempat, peserta, pembawa materi dan sebagainya;

d) Dalam hal pembentukan Keluarga Sadar Hukum (KADARKUM) agar berkonsultasi dengan bidang Hukum Kanwil Kehakiman dan HAM atau Pengadilan Negeri.

Pembinaan kemampuan intelektual:

a) Setiap Narapidana/Anak Didik Pemasyarakatan yang buta huruf, tanpa memandang usia, diberi kesempatan untuk mengikuti pendidikan umum berupa Kejar Paket A atau B. Sedangkan bagi Narapidana/Anak Didik Pemasyarakatan yang akan melanjutkan pendidikannya yang terputus diberi kesempatan untuk mengikuti pendidikan lanjutan sesuai dengan pendidikan terakhirnya;

b) Pelaksanaan pendidikan dilakukan di dalam Lapas;

c) Pelaksanaan pendidikan umum sehari-hari dilakukan oleh Subsi Bimkemaswat;

d) Kesempatan untuk mengikuti pendidikan umum tidak diberikan kepada Narapidana/Anak Didik Pemasyarakatan yang sedang menjalani hukuman disiplin;

e) Tenaga pengajar dapat diambil dari luar LAPAS.

f) Pendidikan umum dilaksanakan berdasarkan kerjasama dengan Departemen/Dinas Pendidikan Nasional, dengan terlebih dahulu seizin Kepala Kantor Wilayah Departemen Kehakiman dan HAM;

g) Bagi Narapidana/Anak Didik Pemasyarakatan yang telah selesai mengikuti pendidikan umum diberikan surat keterangan;

h) Narapidana/Anak Didik Pemasyarakatan yang mengikuti pendidikan umum dicatat dalam buku kehadiran kegiatan pendidikan;

i) Perpustakaan diadakan di ruang tersendiri dengan perlengkapan lemari dan rak buku serta disusun berdasarkan katalog;

\section{7) Pembinaan Sosial Kemasyarakatan}

Pembinaannya berupa:

a) Pembinaan sosial kemasyarakatan dalam bentuk kegiatan kerja bakti, baik di dalam maupun diluar Lapas Narkotika Kelas III Langkat dilaksanakan oleh KPLP.

b) Kegiatan kerja bakti di dalam Lapas Narkotika Kelas III Langkat meliputi: kebersihan kamar hunian, lingkungan kamar/blok, lingkungan perkantoran serta lingkungan halaman dalam Lapas Narkotika Kelas III Langkat, dapat dilakukan secara berkelompok maupun masal.

c) Kerja bakti di luar Lapas Narkotika Kelas III Langkat meliputi kegiatan kebersihan halaman luar Lapas Narkotika Kelas III Langkat atau tempat-tempat tertentu dapat dilakukan atas perintah Kalapas atau permintaan dari instansi lain; Kunjungan keluarga bagi Narapidana/Anak Didik Pemasyarakatan dilaksanakan subsi bimkemaswat bekerjasama dengan KPLP;

d) Narapidana/Anak Didik Pemasyarakatan diperkenankan mengirim dan menerima surat dari keluarga atau pihak-pihak lainnya dengan terlebih dahulu di periksa oleh petugas Bimkemaswat(Skripsi Mahasiswa Fakultas Hukum: UMSU).

\section{8) Pembinaan pencegahan kambuhan}

Pembinaan pencegahan kambuhan dapat dilaksanakan melalui :

a) Case work (bimbingan personal) yaitu bimbingan melalui konseling, konsultasi dan sebagainya yang dilaksanakan oleh dokter, psikolog dan pekerja sosial;

b) Community Organization (bimbingan kelompok) dapat dilaksanakan melalui diskusi kelompok, dinamika kelompok, simulasi dengan materi narkotika.

\section{9) Asesmen}

Asesmen atau pecandraan vokasional bagi Narapidana/Anak Didik Pemasyarakatan narkotika adalah suatu kegiatan yang bertujuan untuk mengantisipasi, menafsirkan dan memprediksikan jenis pekerjaan apa yang dapat dan tepat untuk dilakukan, jika tidak dapat bekerja apa penyebabnya. Narapidana narkotika baru maupun lama harus mengikuti kegiatan-kegiatan yang meliputi:

a) Observasi terhadap keadaan dan perkembangan perilaku narapidana narkotika;

b) Wawancara untuk mendapatkan data kesehatan dan file kasus; 
c) Mengulang data pribadi;

d) Penggalian latar belakang kehidupan dan kondisi pada saat ini;

e) Penggalian bakat dan minat serta potensi;

f) Test psikologi;

g) Riwayat penggunaan narkotika;

h) Pembahasan kasus;

i) Pembuatan Penelitian Kemasyarakatan (Litmas).

Setelah dilaksanakannya pembinaan tahap awal, maka dilakukan pembinaan tahap rehabilitasi yang meliputi:

a)Pembinaan kepribadian dilaksanakan sebagai kelanjutan dari program pembinaan kepribadian yang telah dilaksanakan sebelumnya.

b) Pembinaan kemandirian

c)Berdasarkan keputusan Kalapas terhadap hasil sidang TPP mengenai jenis dan tempat pekerjaan, Kasi Kegiatan Kerja mencatat Narapidana/Anak Didik Pemasyarakatan yang mengikuti kegiatan kerja ke dalam Buku Daftar Kerja;

d) Sebelum melakukan pekerjaan Narapidana/Anak Didik Pemasyarakatan dilakukan:

e)Pengelolaan dan pembukuan hasil kerja Narapidana/Anak Didik Pemasyarakatan dilakukan oleh petugas Kegiatan Kerja;

f) Setiap hasil kerja Narapidana/Anak Didik Pemasyarakatan dikelola sesuai ketentuan yang berlaku;

g) Besarnya upah/premi atau imbalan jasa dari hasil kerja, diatur sesuai dengan ketentuan yang berlaku dan disimpan dalam buku TABANAS yang hanya diketahui oleh Kalapas, pembina, dan yang bersangkutan;

h) Buku TABANAS segera diserahkan kepada Narapidana/Anak Didik Pemasyarakatan, apabila telah selesai menjalani pidana atau dipindahkan ke Lapas lain;

i) Apabila Narapidana/Anak Didik Pemasyarakatan yang bersangkutan meninggal dunia, maka buku TABANAS diserahkan kepada keluarga atau ahli waris narapidana yang bersangkutan.

Pembinaan tahap rehabilitasi merupakan langkah selanjutnya dan diharapkan narapidana dapat melanjutkan menuju pembinaan asimilasi yang merupakan proses pembinaan untuk memulihkan hubungan Narapidana/Anak Didik Pemasyarakatan yang dilaksanakan dengan membaurkan Narapidana/Anak Didik Pemasyarakatan di dalam kehidupan masyarakat dan dilaksanakan secara seimbang antara kepentingan umum dan pembinaan Narapidana/Anak Didik Pemasyarakatan. Narapidana narkotika diberi asimilasi apabila memenuhi persyaratan substantif dan administratif yang telah ditentukan. Adapun asimilasi ini dilaksanakan melalui berbagai bentuk kegiatan, yaitu:

a) Bekerja pada pihak ketiga baik instansi pemerintah, swasta, maupun perorangan;

b) Bekerja mandiri, misalnya menjadi tukang cukur, binatu, bengkel, dan sebagainya;

c) Mengikuti bimbingan berupa pendidikan dan latihan ketrampilan di luar Lapas;

d) Kerja bakti bersama masyarakat;

e) Berolah raga bersama masyarakat;

f) Mengikuti upacara atau peragaan ketrampilan bersama dengan masyarakat;

g) Melaksanakan ibadah bersama masyarakat;

h) Bekerja pada Lapas terbuka dengan tahap minimum security;

i) Cuti mengunjungi keluarga.

Tahapan selanjutnya yang akan diberikan kepada Narapidana/Anak Didik Pemasyarakatan adalah pembinaan tahap integrasi. Pembinaan integrasi diberikan kepada Narapidana/Anak Didik Pemasyarakatan yang telah melalui tahap pembinaan asimilasi dengan baik. Pembinaan integrasi dilaksanakan melalui Pembebasan Bersyarat (PB) dan Cuti Menjelang Bebas (CMB). Narapidana/Anak Didik. Pemasyarakatan yang mengikuti pembinaan integrasi harus memenuhi persyaratan substantif dan administratif yang telah ditentukan.

Baik Undang-Undang Psikotropika maupun Undang-Undang Narkotika mengamanatkan kewajiban untuk menjalani perawatan dan pengobatan atau rehabilitasi bagi pecandu narkoba. Ketentuan mengenai kewajiban untuk menjalani rehabilitasi bagi pengguna yang mengalami kecanduan, dalam Undang-Undang Psiktropika diatur dalam Pasal 36 sampai dengan pasal 39 dan pada Undang-Undang Narkotika diatur dalam Pasal 103.

Karena adanya kriminalisasi terhadap penyalahguna (terutama pemakai) narkoba dan adanya 'mandat' bagi diberikannya tindakan rehabilitasi kepada pecandunya, maka Lapas menjadi institusi negara yang memainkan peran yang sangat penting dalam kebijakan penanganan narkoba. Ia digunakan untuk 'menghukum' dan juga 'menjaga' sejumlah besar orang yang memiliki pengalaman memakai dan bermasalah dengan narkoba. Ia juga memiliki peran penting dalam upaya mengurangi dampak buruk yang disebabkan oleh (pemakaian) narkoba. 
Ketidakjelasan kebijakan dalam hal tujuan pendirian dan kebijakan penempatan tersebut, menurut penulis akan menjadikan efektifitas lapas (khusus narkotika) sebagai tempat pembinaan narapidana (pelaku kriminal) menjadi sangat diragukan. Dalam hal ini, penulis lebih cenderung berpendapat bahwa dengan adanya kriminalisasi pada pengguna narkoba dan mandat undang-undang yang mewajibkan 'diberikannya rehabilitasi bagi pecandu narkoba' maka lapas khusus narkotika akan lebih tepat jika difungsikan sebagai tempat bagi 'membina' penyalahguna narkoba dengan kategori pemakai atau pecandu. Kejelasan kebijakan peruntukan tersebut dengan sendirinya akan memberi pula kejelasan tujuan dan strategi pembinaannya.

Tujuan pembinaan adalah pemasyarakatan yang dapat dibagi kedalam tiga hal sebagai berikut:

a) Setelah keluar dari lembaga permasyarakatan tidak lagi melakukan tindakan pidana.

b) Menjadi manusia yang berguna, berperan aktif, dan kreatif dalam membangun bangsa dan negaranya.

c) Mampu mendekatkan diri kepada Tuhan Yang Maha Esa dan mendapatkan kebahagian dunia maupun akhirat.

Tujuan pembinaan tersebut huruf c Undang-Undang Nomor 12 Tahun 1995 tentang Pemasyarakatan yang menyatakan bahwa, sistem pemasyarakatan merupakan rangkaian hukum yang bertujuan agar warga binaan pemasyarakatan menyadari kesalahannya, memperbaiki diri dan tidak mengulangi tindak pidana sehingga dapat diterima kembali oleh lingkungan masyarakat, dapat aktif berperan dalam pembangunan, dan dapat hidup secara wajar sebagai warga yang baik dan bertanggung jawab.

Narapidana juga manusia, harus dimaklumi adanya kekurangan dan kelemahan dalam dirinya. Walaupun sudah tersesat oleh perbuatannya, masih berhak untuk mendapatkan perlakuan yang layak sebagaimana manusia lainnya. Sebagai makhluk sosial, narapidana tidak diasingkan dari lingkungan masyarakat. Pembinaan yang dilakukan harus ditujukan untuk mengubah tingkah lakunya, menimbulkan rasa tanggung jawab, dan sanggup mencari nafkah secara halal. Setelah menjalani pidananya diharapkan dapat berdiri sendiri sebagai warga masyarakat yang berguna.

Oleh karena itu dalam Keputusan Menteri Kehakiman Republik Indonesia Nomor M.02-PK.04.10 Tahun 1990 dikemukakan bahwa, tujuan pembinaan sesudah menjalani masa pidana adalah sebagai berikut:

a) Berhasil memantapkan kembali harga diri dan kepercayaan dirinya serta optimistis akan masa depannya.

b) Berhasil memperoleh pengetahuan, minimal keterampilan untuk bekal hidup mandiri dan berprestasi dalam kegiatan pembangunan nasional.

c) Berhasil menjadi manusia yang patuh hukum, dan tercermin dalam sikap, perilaku, dan disiplin serta mampu menggalang rasa kesetiakawanan sosial

d) Berhasil memiliki jiwa dan semangat pengabdian terhadap bangsa dan negara.

Kerangka acuan dalam menentukan cara pembinaan narapidana adalah tujuan pembinaan yang harus dapat diwujudkan ketika narapidana selesai melaksanakan hukum pidananya. Harsono menawarkan tentang tujuan pembinaan adalah kesadaran (conciousness) yang dapat dilakukan melalui bebagai tahapan:

a) Mengenal diri sendiri, mengenal hal-hal yang paling mendasar dalam diri sendiri baik hal positif maupun negatif. Mencari jawaban atas pertanyaan dari mana aku ada, dan kemana setelah aku tiada. Memahami diri sebagai individu, sebagai hamba Tuhan, dan sebagai anggota masyarakat.

b) Memiliki kesadaran beragama, sadar sebagai mahluk ciptaan Tuhan yang beriman kepada-Nya, serta sadar melakukan tindakan dan perbuatan sebagai mahluk yang beragama.

c) Mengenal potensi diri, mengembangkan hal-hal positif dalam diri sendiri dan membuang halhal negatif. Memperluas cakrawala pandang, selalu berusaha untuk maju, manambah pengetahuan dam pengalaman, serta pengembangan potensi diri.

d) Mengenal cara memotivasi, mampu memotivasi diri kearah positif dan kearah perubahan lebih baik. Menatap masa depan sebagai harapan, dan menutup masa lalu yang penuh dengan kegelapan.

e) Mampu memotivasi orang lain, kelompoknya, keluarganya, dan masyarakat sekelilingnya agar selalu berusaha untuk maju.

f) Mampu memiliki kesadaran yang tinggi, mengembangkan kreativitas dan berperan aktif dalam membangun bangsa dan negara sebagai wujud kesetiaan terhadap bangsa, negara, Pancasila, dan UUD 1945.

g) Memiliki kepercayaan diri yang kuat, atas dasar yang percaya kepada Tuhan Yang Maha Esa maka ia mampu membangun percaya diri untuk merubah tingkah laku, tindakan, dan keadaan diri sendiri untuk lebih baik lagi. 
h) Memiliki tanggung jawab untuk tetap konsekuen terhadap keputusan yang telah diambil, tindakan-tindakannya, dan mampu menerima segala resiko yang ditimbulkannya.

i) Menjadi pribadi yang utuh, mampu menghadapi segala tantangan, hambatan, halangan, rintangan, dan masalah apapun dalam setiap langkah dan kehidupannya.

Dalam melaksanakan pembinaan narapidana diperlukan dasar-dasar pembinaan untuk menjadi pegangan bagi para pembina agar tujuan pembinaan dapat diwujudkan. Dalam Undang-Undang Nomor 12 Tahun 1995 tentang Pemasyarakatan, dikenal istilah asas pembinaan yang pada pasal 5 disebutkan tujuh asas dalam sistem pembinaan pemasyarakatan sebagai berikut :

a) Asas pengayoman, yaitu perlakuan terhadap warga binaan pemasyarakatan dalam rangka melindungi masyarakat dari kemungkinan diulanginya tindak pidana oleh warga binaan pemasyarakatan. Selain itu, juga memberikan bekal hidup kepada warga binaan pemasyarakatan agar mereka menjadi warga yang berguna di dalam masyarakat. Asas tersebut berkaitan dengan fungsi hukum untuk melindungi masyarakat, termasuk melindungi warga binaan pemasyarakatan. Tidak boleh terjadi pembalasan dendam kepada narapidana yang telah melakukan kesalahan, sebab LAPAS adalah tempat untuk pembinaan pemasyarakatan.

b) Asas persamaan perlakuan dalam pelayanan, dimaksudkan agar para pembina pemasyarakatan memberikan perlakuan dan pelayanan yang sama terhadap warga binaannya tanpa membedabedakan orang. Asas tersebut sejalan dengan pasal 27 ayat (1) UUD 1945 yang menegaskan bahwa, semua warga negara Indonesia mempunyai kedudukan yang sama di depan hukum dan pemerintahan.

c) Asas pendidikan, warga binaan pemasyarakatan mendapat pendidikan yang dilaksanakan berdasarkan Pancasila. Pendidikan tersebut diarahkan untuk menanamkan jiwa kekeluargaan, mengembangkan ilmu pengetahuan dan keterampilan, pembinaan kerohanian, dan memberikan kesempatan menunaikan ibadah sesuai dengan agama dan kepercayaan masing-masing.

d) Asas penghormatan harkat dan martabat manusia, hal ini dimaksudkan agar dalam melaksanakan pembinaan tetap harus memperlakukan warga yang dibina sebagaimana layaknya manusia. Sebagai manusia harus tetap dihormati harkat dan martabatnya, dan jika dilalaikan maka terjadi pelanggaran hak asasi manusia.

e) Asas penghormatan harkat dan martabat manusia, hal ini dimaksudkan agar dalam melaksanakan pembinaan tetap harus memperlakukan warga yang dibina sebagaimana layaknya manusia. Sebagai manusia harus tetap dihormati harkat dan martabatnya, dan jika dilalaikan maka terjadi pelanggaran hak asasi manusia.

f) Asas kehilangan kemerdekaan merupakan satu-satunya penderitaan, menurut penjelasan undangundang bahwa warga binaan pemasyarakatan harus berada dalam LAPAS untuk jangka waktu tertentu, sehingga negar mempunyai kesempatan penuh untuk memperbaiki. Seseorang yang dihukum pidana penjaran atau kurungan harus menjalani pidananya di LAPAS, selama berada di dalam LAPAS inilah yang merupakan kehilangan kemerdekaannya, artinya ia tidak bebas untuk pergi kemana-mana. Walaupun kehilangan kemerdekaannya sebagaimana dimaksud, akan tetapi hak perdatanya tetap dilindungi didalam LAPAS seperti hak memperoleh perawatan kesehatna, makan, minum, pakaian, tempat tidur, latihan keterampilan, olahraga, atau rekreasi.

g) Asas terjaminnya hak untuk tetap berhubungan dengan keluarga dan orang-orang tertentu, selama narapidana mendapat pembinaan di LAPAS, mereka tetap dijamin haknya untuk berhubungan dengan keluarga dan orang-orang tertentu. Pada prinsipnya untuk membina narapidana tidak boleh diasingkan sama sekali dengan masyarakat. Disamping boleh berhubungan dengan keliarga, narapidana juga boleh berhubungan dengan orang-orang tertentu misalnya ada pejabat dalam dan luar negeri yang berkunjung ke LAPAS, rohaniawan, seniman dan lain-lain.

Pembinaan warga binaan pemasyarakatan dilakukan dengan dua cara yaitu intramural (di dalam LAPAS) dan extramural (di luar LAPAS). Pembinaan extra mural yang dilakukan LAPAS dikenal dengan nama asimilasi, yaitu proses pembinaan warga binaan pemasyarakatan yang telah memenuhi persyaratan tertentu dengan membaurkannya ke dalam kehidupan masyarakat. Pembinaan extramural yang dilakukan BAPAS disebut integrasio, yaitu proses pembinaan warga binaan permasyarakatan yang telah memenuhi persyaratan tertentu untuk hidup dan berada kembali di tengah-tengah masyarakat dengan bimbingan dan pengawas BAPAS.

Menurut Undang-Undang Nomor 12 Tahun 1995 tentang Pemasyarakatan, Pasal 9 menyatakan bahwa, dalam rangka penyelenggaraan pembinaan dan pembimbingan warga binaan kemasyarakatan, Menteri dapat mengadakan kerjasama dengan instansi pemerintah terkait, dan badan-badan kemasyarakatan lainnya, atau perorangan yang kegiatannya seiring dengan penyelenggaraan sistem pemasyarakatan sebagaimana dimaksud dalam Pasal 2 dan 3. Tujuan kerja sama tersebut adalah 
meningkatkan kemampuan warga binaan pemasyarakatan dibidang keterampilan, kesadaran beragama, ilmu pengetahuan dan keintegrasian dengan masyarakat.

Pada dasarnya arah pelayanan, pembinaan dan bimbingan yang perlu dilakukan adalah meperbaiki tingkah laku warga binaan pemasyarakatan agar tujuan pembinaan dapat tercapai. Ruang lingkup pembinaan terbagi dalam 2 bidang yaitu:

a) Pembinaan kepribadian.

b) Pembinaan kemandirian.

\section{b. Kendala dalam Rehabilitasi}

Banyaknya kejadian penemuan, pemakaian, bahkan produksi serta transaksi narkoba di Lapas berdampak pada makin buruknya citra Lapas (khusus narkotika). Di masyarakat bahkan berkembang anggapan bahwa lebih mudah mendapatkan narkoba di lapas dari pada di luar lapas bahkan banyak pengedar tetap mampu menjalankan bisnisnya dari dalam penjara. Lapas dianggap sebagai surganya peredaran narkoba.

Anggapan-anggapan tersebut tidak dapat diabaikan begitu saja karena bukan tidak mungkin akan membawa dampak yang buruk. Buruknya citra Lapas (Narkotika) berdampak pada adanya 'penolakan' atas berdirinya Lapas Narkotika di suatu daerah karena dianggap bahwa justru pendirian Lapas tersebut akan berdampak negatif bagi masyarakat sekitar Lapas.

Penegakan hukum selalu akan melibatkan manusia didalamnya dan dengan demikian akan melibatkan tingkah laku manusia juga. Hukum tidak bisa tegak dengan sendirinya, artinya tidak akan mampu mewujudkan janji-janji serta kehendak-kehendak yang tercantum dalam peraturan hukum tersebut. Hukum tidak akan bisa tegak dengan sendirinya tanpa adanya aparat penegak hukum seperti polisi yang bisa dan optimal menjembataninya.

Hal ini menunjukkan tantangan yang dihadapi oleh aparat penegak hukum dalam rangka law enforcement bukan tidak mungkin sangatlah banyak. Penegak hukum bukan hanya dituntut untuk profesional dan pintar di dalam menerapkan norma hukumnya secara tepat, tetapi juga harus berhadapan dengan seseorang dan bahkan sekelompok anggota masyarakat yang diduga melakukan kejahatan.

Kendala yang dihadapi pihak Lapas Narkotika dalam melakukan rehabilitasi yaitu: (Skripsi Mahasiswa Fakultas Hukum: UMSU).

1) Minimnya anggaran biaya operasional, sarana dan prasarana

Miniminya anggaran biaya opersional merupakan hambatan yang sering kali dijumpai yaitu pihak Lapas merasa kesulitan dalam melakukan rehabilitasi karena biaya operasional sangat minim sehingga menghambat kerja pihak Lapas. Begitu juga mengenai sarana dan prasarana yang minim dapat menghambat kerja pihak Lapas.

2) Kurangnya Teknologi dan Teknisi

Kurangnya teknologi merupakan hambatan yang ditemui pihak Lapas di jaman yang sangat canggih seiring perkembangan jaman maka sebaiknya Lapas juga dibekali teknologi yang canggih pula agar tidak menjadi hambatan dalam menanggulangi kejahatan. Contohnya: komputer. Sedangkan kurangnya teknisi yang menjadi penghambat kerja pihak Lapas yaitu kurangnya anggota yang dapat menggunakan teknologi, oleh karena itu dibutuhkan anggota yang benar-benar professional dalam melakukan tugasnya

3) Kurangnya jumlah personil

Kurangnya jumlah personil yang merupakan penghambat kerja pihak Lapas karena jumlah personil yang tidak memadai dalam melaksanakan proses rehabilitasi. Seperti yang diketahui bahwa personil yang memadai hanya berjumlah sekitar dua puluh lima orang, sedangkan personil yang lain sudah pensiun dan sebagian personil lainnya telah dimutasi ke bagian lain.

\section{SIMPULAN dan SARAN}

\section{Kesimpulan}

Penetapan pelaksanaan rehabilitasi terhadap pengguna narkoba merupakan salah satu bagian dari vonis yang dijatuhkan oleh Hakim dan tempat dimana Vonis itu dilaksanakan seharusnya adalah adalah lembaga Pemasyarakatan, bukan ditempat lain. Hal yang sangat disayangkan adalah kurangnya perhatian pemerintah maupun pihak-pihak pembuat kebijakan lain untuk mengatur hal-hal yang bersifat detail mengenai bagaimana hal itu diterapkan. Akibatnya adalah aturan hukum sebagaimana yang disebutkan dalam Undang-undang Psikotropika maupun Narkotika mengenai penerapan hukuman rehabilitasi tersebut hanyalah tinggal pemanis undang-undang tersebut saja tanpa dapat benar-benar secara nyata dan menyeluruh diterapkan dalam aplikasinya dilapangan.

Lembaga Pemasyarakatan, harus diakui sudah banyak mengeluarkan kebijakan-kebijakan yang dapat mengakomodir hak-hak dari para Terpidana kasus Narkoba. Namun hal itu masih dalam taraf yang 
bersifat umum, sedangkan dalam hal-hal khusus seperti penanganan terhadap Terpidana Narkoba yang berada pada tingkat hanya sebagai pengguna masih belum cukup diperhatikan.

\section{Saran}

Hendaknya para petugas Lembaga Pemasyarakatan/Rumah Tahanan Negara diberi kesempatan untuk menambah pengetahuan melalui berbagai penataran yang bertalian dengan tugas-tugasnya dan sekali-kali melakukan kunjungan ke Lembaga Pemasyarakatan/Rumah Tahanan Negara lain dalam rangka pertukaran pengalaman. Selain itu buku-buku tentang literatur Ilmu Pemasyarakatan beserta peraturan-peraturannya perlu diberikan sebagai pedoman dalam bertindak.

Dalam upaya mencapai penyelenggaraan Sistem Pemasyarakatan yang menyeluruh hal ini tidak perlu dihapuskan dengan menyeragamkan semua sistem. Dengan cara begitu dimungkinkan guna perkembangan system pembinaan baru yang berorientasi pada nilai-nilai yang hidup dimasyarakat; Kesadaran masyarakat akan pentingnya resosialisasi (memasyarakatkan) narapidana itu perlu ditumbuhkan demi kebaikan masyarakat itu sendiri.

\section{DAFTAR PUSTAKAAN}

Djamal, R, Abdoel Pengantar Hukum Indonesia. Jakarta: RajaGrafindo Persada. 2001.

Harsono, C.I. Sistem Baru Pembinaan Narapidana. Jakarta: Djambatan. 1995.

Imron, Rosyadi. Penegakan Hukum dalam Masyarakat Indonesia. Jurnal Sains dan Inovasi III No. 2 Tahun 2007.

Marzuki, Mahmud, Peter. Penelitian Hukum. Jakarta: Kencana Prenada Media Group. 2011.

Mertokusumo, Sudikno. Mengenal Hukum (Suatu Pengantar). Yogyakarta: Cahaya Atma Pustaka. 2010.

Nashriani, Perlindungan Hukum Pidna bagi Anak Indonesia. Jakarta : PT Raja Grafindo 2012.

------Pengantar Penelitian Hukum. Jakarta: UI Press. 1996.

Prints, Darwin. Hukum Anak Indonesia. Medan : PT.Citra Aditya Bakti. 1997.

Rahardjo, Satjipto. Ilmu Hukum. Bandung: PT Citra Aditya Bakti. 2006.

Rahardjo, Satjipto. Penegakan Hukum Suatu Tinjauan Sosiologis. Yogyakarta: Genta Publishing. 2009.

Santoso, Topo. Suatu Tinjauan Atas Efektivitas Pemidanaa. Dalam seri unsur-unsur penyusun bangunan negara hukum. Hukum Pidana dalam Prespektif. Jakarta: Pustaka Larasan. 2012.

Sasangka, Hari. Narkotika dan Psikotropika dalam Hukum Pidana untuk Mahasiswa dan Praktisi Serta Penyuluh Masalah Narkoba. Mandar Maju. Bandung. 2003.

Seokanto, Sorejono dan Sri Muji. Penelitian Hukum Normatif Suatu Tinjauan Singkat. Jakarta: Rajawali Pers. 2003.

Supramo, Gatot. Hukum Acara Pengadilan Anak. Jakarta : Djambatan. 2000.

Utsman. Sabian Menuju Penegakan Hukum Responsif. Yogyakarta: Pustaka Pelajar. 2010.

\section{Peraturan Perundang-Undangan:}

Undang-Undang No. 35 tahun 2009 tentang narkotika

Surat Edaran Mahkamah Agung No. 4 tahun 2010

Undang-Undang Nomor 22 Tahun 1997 tentang Narkotika

Undang-Undang Nomor 12 Tahun 1995 tentang Pemasyarakatan

Keputusan Menteri Kehakiman RI Nomor: M.02-PK.04.10 tanggal 10 April 1990 tentang Pola Pembinaan Narapidana dan Tahanan

Undang-Undang Nomor 12 Tahun 1995 tentang Pemasyarakatan

Undang-Undang Dasar UUD 1945

\section{Hasil Penelitian:}

Skripsi Mahasiswa Fakultas Hukum:UMSU, Rehabilitasi Terhadap Narapidana Narkotika Yang Diselenggarakan Lembaga Pemasyarakatan (Studi di Lapas Narkotika Kelas III Langkat). 